\title{
4
}

\section{Declining opposition to betting on racing}

$\bigvee \begin{aligned} & \text { hen Mass Observation studied Bolton in } 1938 \text { it noticed a number of } \\ & \text { 'major oppositions' which cut across the life of the community, sepa- }\end{aligned}$ rating married couples and families - issues about which persons apparently alike with respect to income, age, appearance or knowledge might violently differ or feel resentment. One was the drinking of alcohol. Another was betting. ${ }^{1}$ They were defined as part of dominant popular culture or as part of oppositional culture, depending on one's social identity. Betting was an intensely social activity, which avoided direct competition within families or communities by focusing interest on indirect competition between horses and jockeys. Even if people disagreed about a horse's chances, the only personal competition for the punter was between him and the bookmaker. Yet betting aroused powerful emotions and strong opposition in wider British society. To understand its place we need to examine the nature of the opposition to betting, and those who disliked it, found it irrelevant or disagreed with it, now we have examined those who enjoyed betting, accepted it or felt involved with it.

Over much of the nineteenth century there had been 'respectable' opposition to both racing and betting, but by the early part of the twentieth century there was less opposition to racing itself. ${ }^{2}$ The practice of offering alternatives to the race meetings continued in the form of events like the Newcastle 'Hoppings' or in the common arrangements made by Sunday schools to take their pupils away during the races. The Middlesbrough Sunday School Union, for example, organised extra excursions each year during Stockton Race Week, and 13,000 travelled by their trains in $1921 .^{3}$ But people could take an excursion trip one day, and attend the races another. Even arguments against the cruelty to horses had less impact, although Aintree in particular continued to attract RSPCA proposals for change, and letters of complaint to the press. ${ }^{4}$ 
Declining opposition was due partly to the decreased visibility of racing's noisy crowds, since courses had increasingly moved away from town centres. For example, in 1882 Leicester's meeting had moved out to Oadby, and Newcastle's to Gosforth Park, while Nottingham's went to Colwick Park in 1892. In part too the increasing enclosure of courses and the creation of more sub-enclosures within them had made behaviour easier to control, while upperand middle-class support for approved courses was more overt. Another reason was the great increase in the volume of working-class off-course betting, although from the 1890s this attracted vociferous campaigns of opposition. Although such opposition spread to other forms of popular gambling, its application to racehorse betting is the main focus here.

\section{Anti-gamblers' arguments}

Between the wars gambling was growing in popularity, while anti-gambling and anti-betting feeling was losing some of its power. The peak in negative feeling amongst a vociferous section of middle-class and respectable working-class society was the later nineteenth century. The keynote of their anti-gambling strategy was the state prohibition of working-class cash betting via the 1853 Betting Houses Act and the Street Betting Act of 1906, alongside the preservation of legal on-course betting and bookmakers in the interests of horseracing and upper-class gamblers. ${ }^{5}$ This class-discriminatory policy had at best only slowed down the increase in gambling, but the anti-gambling movement still had the support of many Liberal, Labour and Nonconformist church leaders and members, and opposition to betting clearly crossed class boundaries.

This meant that punters were always conscious of the 'anti-gamblers', that powerful minority of the population who supported state action against gambling. Those about whom we know most, those who opposed betting more publicly, were strong in their certainty. They cared about the issue. They spoke with passion. Many, though not all, were Christians, with a faith that transcended the material world. Their dominant rhetoric reflected a long-standing and powerful Protestant tradition. Although they were in a minority, they often held power within local communities. They were leaders in politics, on the magistrates' bench, press editors or local businessmen. What they said could not be ignored. Punters saw the displayed notices banning betting in public houses, the notices about the consequences of betting outside churches, or came across reports of anti-betting sermons in church, and perhaps felt guilty. Religious rituals spoke of the sacred, betting rituals of sin. 
Protestantism rather than class was the major determinant of attitudes. Protestantism stressed prudence, rationality and thrift. To the Nonconformist, work, merit and reward went hand in hand. Gambling was based on chance and thus undermined 'proper' ethical approaches to life. It violated the legitimate ethical, economic and social system. It attacked modern economic life. It was a competing and thus highly dangerous subculture. Yet Nonconformist industrial success was based on similar values to those exhibited by gamblers, including competitiveness, boldness, innovation and risk-taking, although these were carefully rationalised by industrialists and their biographers. Luck was not supposed to play a part in their lives, so they were portrayed as models of ability and diligence, prudence and perseverance, even if their rewards were extreme due to high-risk investments. There were always hidden elements of tension, ambivalence and guilt about the anti-betting position, and the relationship between cash and culture was always ambiguous. The cultural theorist Dyer has pointed out that popular entertainments like betting provided apparent alternatives to capitalism in a capitalist form. ${ }^{6}$ To cope with this, antigambling groups tried hard to culturally locate betting in spheres of activity which could be presented as segregated, differentiated and illegitimate, so its norms did not challenge the 'legitimate' economy. Most of their efforts were directed towards permissible and desirable attacks on illegal aspects of betting, such as sweepstakes or cash betting. Gambling functioned as their scapegoat, a target for potentially disruptive ambivalences, a useful symbol for guilt projection. ${ }^{7}$ Self-made Nonconformist industrialists were admirable folk heroes; grasping, greedy, gambling bookmakers were folk villains, targets of righteous indignation. Such dualisms strengthened anti-gambling opposition.

The anti-gamblers' genuine feelings were also stirred by direct experience of what they saw as the immorality and ruinous social consequences of gambling. Their experience, like that of the gamblers, was social, mutually reinforcing and self-confirming. They preached about it, talked about it and shared their observations. Being an 'anti-gambler' was part of their self-identity. They met with and wrote to others. As the Salford-based Canon Peter Green explained, his 'best source of information' on gambling was drawn from his 'wide circle of friends' of all classes. These friends were:

godly policemen, devout soldiers, earnest foremen and forewomen - Sunday School teachers in their spare time, at some church or chapel, and horrified at what they see going on all round them - newly confirmed boys and girls trying to stand for Christ in the workshops, big employers of labour, magistrates of both sexes amazed at the revelations that come to them on the bench, doctors and other professional men. ${ }^{8}$ 
Green wanted others to learn gambling's evil. He validated his views by pointing them to the evidence. Anti-gamblers constantly found the evidence for which they constantly searched. This mutually-shared experience of selected aspects of the social pathology of gambling structured and shaped their understandings, so it was unsurprising that their evidence was uniform in its condemnation of betting's role. Their dominant model of the punter was a dupe on an inevitable road to disaster. So they did not question average, unproblematical punters, who remained shadowy figures.

In the self-validating circles in which most anti-gamblers moved, betting was unrespectable. So they often lacked any real understanding that betting was widely perceived as a rational act. Anti-gamblers tended to present themselves as of higher status, as intellectually, morally and ethically superior. Green contemptuously dismissed all betters as intellectually dull, claiming they showed no 'symptoms of intelligence'. 'His arguments focused on the physical, social, moral and economic effects of excessive betting, which he then applied to most betters. The anti-gamblers studied these effects as a social problem, but divorced betting from its cultural context. There is never any impression that any had ever placed a bet themselves.

Because so many anti-gamblers held strong Christian beliefs, they talked about betting in religious, ethical and medical language. Gambling seemed to pose a direct challenge to their faith. The Christian Social Council in 1932 stated firmly that 'gambling challenges that view of life which the Christian Church exists to uphold and defend'. ${ }^{10}$ Betting was a 'sin' to those in the Nonconformist churches, but publicly they rarely used the word. It was probably deliberately avoided when giving evidence about gambling in secular public contexts. In part this was because the question of whether it was a sin was an area of debate amidst Christian moral theologians, and this potentially weakened anti-gambling arguments. The Roman Catholic Church accepted betting fairly easily, as it did the drinking of alcohol, unless it was excessive, and Catholic moral theologians argued that gambling was not essentially sinful. ${ }^{11}$ The Church of England was divided. On the one hand, an article in the Church Times in 1923 argued that 'a very strong case can, as our readers are aware, be made to show that under certain conditions the practice is not morally blameworthy'. ${ }^{12}$ On the other, Church of England anti-gamblers argued that this was 'a sin against God'. Combating it was part of one's duty; part of the doctrine of good stewardship. Increasingly the latter view gained strength in the early 1930s, as those then moving into senior posts were opposed to gambling. William Temple, a future archbishop of Canterbury, 
collaborated on a book on gambling and ethics. ${ }^{13}$ Anti-gambling became Protestant orthodoxy.

The distribution of strong religious opposition to gambling in the 1920s was illustrated by resolutions sent in to the 1923 Select Committee on Betting Duty. Almost all of these came from Nonconformity, and were the result of an active campaign waged within their convocations to encourage the forwarding of resolutions. The Wesleyans, who had an active membership of 470,000, and claimed over a million and a half worshippers, organised resolutions against the imposition of betting duty in all thirty-three synods in England, Scotland and Wales. Ministers made up 25 per cent of synod membership and the real extent of lay support remained unclear. Other senders of resolutions included the Sunday School Union, which claimed a membership of three million, and the Evangelical Free Churches, who claimed a membership of two million. If all members of these churches were strong in their anti-gambling beliefs therefore, this was indeed powerful opposition. Yet reports of

Table 4.I Resolutions sent in to the Select Committee on Betting Duty, 1923

\section{Organisation}

Free Church Council

Sunday School Union

Brotherhood Movement

Primitive Methodist Church

Wesleyan Methodist Church

United Methodist Church

Calvinistic Methodist Church

Independent Methodist Church

Baptist Church

Congregational Church

Society of Friends

United Free Church of Scotland

Free Presbyterian Church of Scotland

Reformed Presbyterian Church of Scotland

Presbyterian Church of England

Presbyterian Church of Wales

Moravian Church

Miscellaneous

No. of resolutions received

85

61

279

365

311

35

16

3

147

122

3

8

2

।

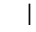

।

।

92

Source: 1923 Select Committee on Betting Duty, minutes of evidence 
local meetings occasionally provide a more mixed picture. At a South Caernarvonshire Congregational Association meeting, for example, when the chair moved a resolution deploring gambling, and others spoke in favour, there were three dissenting voices, arguing that this was hypocritical since the church had raffles, while 'church deacons and even women members were said to be amongst those addicted'. ${ }^{14}$

Christians who gave anti-gambling evidence to the 1923 Select Committee on Betting Duty included the Rev. Benson Perkins, assistant secretary of social welfare for the Wesleyans; Rev. Robert Gillie, an ex-president of the Sunday School Union and of the National Council for Evangelical Free Churches; Rev. Hon. E. Lyttleton, a former head of Eton; Dr Welldon the Dean of Durham; and Canon Peter Green, whose unscientific generalisations had a particular impact on the Committee's report. To avoid the potential problems of discussing gambling as a sin in a secular context, the word they much more regularly applied to gambling was 'evil'. In religious terms fighting against gambling was part of the eternal struggle, and so the term 'evil', preceded by adjectives like 'gigantic', 'inherently' or 'national', was the main noun applied to gambling, permeating the anti-gambling evidence given. Gambling was described as the greatest evil in the country, a 'habit that cannot be cured' except by moral and spiritual means. ${ }^{15}$ In 1925 the Society for the Propagation of Christian Knowledge published a thirty-one-page pamphlet explaining A Christian View of Gambling, making it clear that betting was an 'evil' sin. Later organisations and individuals maintained this choice of words. In his 1930 book Gambling and Christian Ideals, for example, Cecil Rose described it as 'one of the greatest social evils of our times'. ${ }^{16}$

For these more religious anti-gamblers, moral arguments had priority. In earlier attacks on betting, it had been seen as wrong largely because of its effects. ${ }^{17}$ The campaigns of the interwar years had a more strongly moralistic tone running alongside restatements of the earlier arguments. A tax on betting would be morally disastrous, a serious condemnation from the view of Christian citizenship. Betting was a weakness which reduced moral qualities, not just those of the individual, but in a much wider sense. Green summed up such arguments in terms of Christian duty. To combat it was part of one's duty to God. It was also part of one's duty to oneself, since gambling was unquestionably injurious to character. It did not help the gambler to 'say his prayers and to worship God ... or be zealous in good works to his neighbour or keen on matters touching public welfare'. Betting was a 'sin against one's own soul'. Antigambling was part of the duty to one's neighbour because getting money out of 
someone else could 'do financial harm to them and set a bad moral example'. It was anti-social and selfish. It was also a sin against 'all men, a sin against society', which wasted wealth, ruined the innocent and made homes miserable. ${ }^{18}$ It had a further moral cost to the nation, in taking men from the Church, night school and education. More betting would 'weaken the moral strength of the nation and therefore lessen the moral influence of Great Britain in the thought and life of the world'. ${ }^{19}$

Betting was also seen as irrational, appealing to chance and rejecting reason. Lotteries allowed huge amounts of money to be won by sheer luck, a denial of the Protestant virtues of thrift and hard work. As the archbishop of York explained, introducing the evidence of the churches to the 1932/3 Royal Commission, 'as a social factor its essence is the distribution of wealth on the basis of chance $\ldots$ that is plainly indefensible'. ${ }^{20}$ It encouraged superstitious beliefs and a preoccupation with luck, and fostered laziness, irresponsibility and fatalism. It encouraged workers to be spendthrift and hedonistic, wasting time and money.

While for Christian anti-gamblers the main arguments were ethical and moral, some Christians did not share their views, and in an increasingly secular society religious arguments alone were losing their power to persuade. Secular arguments about the effects of gambling had always been a commonplace of the anti-gambling position, and the ever-growing variety of popular gambling forms caused alarm to a range of other, more secular interest groups. By the time of the 1932/3 Royal Commission on Lotteries and Betting, the constituency giving anti-gambling evidence included groups such as social workers, probation officers and charity organisations, and had proportionately fewer overt Christian anti-gamblers such as the archbishop of York and the bishop of Manchester. ${ }^{21}$

Opposition to betting and gambling therefore also covered a range of arguments concerned with the economic, physical and social damage they caused. Firstly anti-gamblers argued that attempts to legalise betting were 'condemned by experience'. They appealed to the weight of history, arguing that repeated judgments against the legalisation of betting over the last century years were 'presumptive evidence' of the principle. ${ }^{22}$ The allegedly pernicious effects of the lotteries in the early nineteenth century, the betting houses of the early 1850 s, or the street betting of the late nineteenth century were regularly cited as reasons not to make any retrograde move. Any weakening of laws against betting, such as introduction of a betting duty, would be a state sanction of a national evil. State dependence on gambling revenue would implicitly endorse betting, 
and would lead to increased levels of betting activity, and thus increased social problems.

The experience of other countries was also cited as an argument against making betting easier, although examples were selected which favoured the anti-gambling cause. It was claimed that in New Zealand the state sanction and support provided by the betting tax on bookmakers and the introduction of the Totalisator had added enormously to the volume of betting. Softening of the law would therefore be counter-productive. Countries such as Canada were praised for introducing new laws to ban the advertising of betting facilities.

Other arguments were located in the economic and social spheres. Betting was seen as being based on unsound economic principles. Betting was an 'illegitimate form of exchange' - to be contrasted with the Protestant ethic of legitimate forms. ${ }^{23}$ It was an unproductive occupation and an illegitimate form of profit- or loss-making activity. No service was provided, the anti-gamblers argued, and betting weakened the sense of value, so hard work was impossible, and people stopped trying to save. Any gain in state revenue by taxation would be outweighed by the weakening of the economic foundations of society. In their eyes there were only three legitimate forms of exchange - value, labour and benevolence - and in their eyes betting satisfied none of these. It depreciated the sense of values which people ought to possess, and encouraged unhealthy speculation. In part such arguments were also about the right use of money. Whilst some argued that money could be spent on betting without appreciably affecting income, the anti-gamblers argued that such money could be spent to much better purpose. They also took the view that money easily won was generally spent recklessly.

Some saw the issue in wider economic terms and linked arguments to more structural economic features such as concerns over competition with USA and Germany. To Arthur Shadwell, betting had 'an injurious influence on industrial efficiency'. ${ }^{24}$ In this view obsession with betting hindered production. The Accrington chief constable felt that betting in mills and factories tended to 'draw the attention of workers from their work'. ${ }^{25}$ Work was stopped and damaged by the amount of time given to discussion and thought about betting. Canon Green claimed to have gathered supporting qualitative evidence from workshops, mills, warehouses, offices, mines, builders' yards and railways, and argued that while owners supported him and gave him information, they would not provide statistics which put them competitively in a bad light. He was certain that gambling affected production, and that this was made worse because some overlookers, supervisors and foremen actually coerced people to bet. 
People even read betting papers in the toilet. He estimated that betting created a 20 per cent national loss of production due to wasted time, wasted material and the internal friction that betting created. There were also safety issues, a point he illustrated with one anecdote describing a railway signal operator using his safety phone to get racing results, and then leaving his signal box to walk down the track to pass on the results to nearby pub bowls players. ${ }^{26}$ To a more limited extent gambling was putatively linked to the rise of socialism, and what the 1923 Select Committee chair called the 'something for nothing' arguments about society. ${ }^{27}$

Any betting gains were at the expense of another's losses, so all gamblers, and most especially bookmakers, could be demonised as predatory. The demonisation of bookmakers was associated with the belief that 'without bookmakers there would be no betting'. ${ }^{28}$ There was therefore real concern that licensing and hence legalising large numbers of cash bookmakers would create a new 'vested interest', a new national institution. In fact it was in large part the opposition to gambling that had forced bookmakers to become an increasingly powerful political lobby in the first place. The National Sporting League had first been founded around 1900 for political reasons to defend racing and betting. Its membership was varied, but it had a large number of small-bookmaker members. They raised funds used at election times to back candidates who supported racing or to oppose those who did not. Indeed in 1929 they put pressure on the Conservative government to abandon betting taxation by lending their support to the Labour Party at the North Lanarkshire by-election, even though Labour opposed betting.

While moral arguments had only very limited effect outside the movement, and the economic arguments were finely balanced, the evidence that excessive betting could have profound social effects was much more influential in wider society. By 1932 it was this aspect which most concerned the Royal Commission on Lotteries and Betting. The Commission recognised that there were no available social statistics, and so was anxious to talk to experienced witnesses with first-hand knowledge. Its 1932/3 Final Report had a special section on the 'social effects of betting at the present time', which covered 'Gambling and Impoverishment', 'Gambling and Crime', and 'Effects on Character'.

Most people recognised that excessive gambling could lead to poverty, and that if gamblers gambled more than they could afford this could have social costs. Families were ruined thanks to betting, and it was argued to be a cause of working-class poverty. F. B. Meyer wrote in 1922 that he could 'recite story after 
story of men whose lives, homes and prospects have been destroyed by the insidious ravages of the betting craze' ${ }^{29}$ Anti-gambling evidence in 1932/3 claimed that a significant proportion of poverty was caused by gambling, while unemployed men, receiving dole money, were wasting their meagre resources on betting. There were 'a considerable number of cases' where gambling and not drunkenness was the main cause of household distress and family destitution. ${ }^{30}$ The Royal Commission took the view that impoverishment due to gambling was not uncommon, and that in very many cases sums are being spent on gambling which on any reasonable view ought to be devoted to the proper support of the home'. ${ }^{31}$

Gambling was also presented as a frequent cause of crime. The earlier 1906 Street Betting Acts had been passed because of concerns about betting as a contributory factor to working-class poverty and crime. The results of gambling supposedly placed a heavy economic burden on the trading community, including losses because of theft, possible bankruptcy and consequent outrelief. Such concerns resurfaced powerfully in the anti-gambling evidence given to both the 1923 Select Committee and the 1932 Royal Commission. ${ }^{32}$ Fraud and embezzlement were perhaps the two most common middle-class major crimes, and in anti-gambling rhetoric such crimes were often seen as having a direct link to betting. According to the leading anti-gambling organisation, the National Anti-Gambling League (henceforth NAGL) in May 1919 'more crime and misery are attributable to it than any other national evil, not excluding intemperance', and this was a generally-held view. ${ }^{33}$ Betting was supposedly a strong temptation for clerks and others handling large sums of money for their employers. ${ }^{34}$ Whilst no statistical evidence for this was provided, it was claimed to be a matter of common experience that betting encouraged employees to steal from employers to feed their habit. Discovery and ruin was the final result. Green cited many individual examples, and in 1923 estimated that betting was responsible annually for 100,000 suicides, thefts and bankruptcies. ${ }^{35}$ The 1923 Committee was less convinced, suggesting that the few available statistics did not show any increase in the last years, rather the reverse. The anti-gamblers had explanations. It was due to the increasing leniency of magistrates, or perhaps firms didn't go to court to avoid bad publicity, but simply sacked offenders and refused to provide a reference. Anti-gamblers and police who gave evidence to the 1932/3 Commission generally avoided statistics, but argued that there were 'many' or 'numbers of cases', and that it was 'a very large factor' and played 'a very prominent part'. The chief constable of the West Riding claimed that of the 457 embezzlement 
and fraudulent conversion claims of the last 5 years, gambling had been a factor in 58 cases. Such evidence led the Commission to conclude that the weight of evidence shows that gambling is responsible for a considerable proportion' of such cases. ${ }^{36}$

Gambling was also linked to violent crime. The anti-gamblers noted the evidence of racecourse criminality. They saw betting as a means whereby violent criminals were recruited. The violent outrages of the London and Birmingham race gangs, the outbreaks of violence on small courses, the blackmail and extortion practised upon bookmakers, were all seen as further evidence of its potential dangers. ${ }^{37}$ Also linked to criminality was the recognition that betting caused demoralisation and corruption amongst the police, and that many apparent convictions were bogus. Green claimed that in Salford there was an almost universal and unshakeable belief amongst workers that the plain-clothes men of the detective department were hand in glove with the bookmakers and were bribed by them. ${ }^{38}$

Evidence to the 1923 Select Committee and the 1932/3 Commission emphasised betting's negative effects on character, especially in young people. Social workers claimed that 'the whole outlook of young men and boys becomes changed' and were 'only too well aware of the deterioration of character that follows upon the gambling habit'. Commissioner Lamb referred to its effects on children. The secretary of a Mile End club for young men said that it made them 'disgruntled', and 'loungers'. ${ }^{39}$ 'Youth' were seen as particularly attracted to it. Children after the war were being 'brought up with less discipline' and now had 'a natural instinct for self-gratification'. ${ }^{40}$ Opponents of a betting tax argued that it was the duty of the state to safeguard child development by eliminating or restricting such temptations to gamble.

Betting was presented as a 'menace to wholesome social life'. ${ }^{41}$ Sexual roles were threatened by gambling and many of the anti-gamblers argued in lectures, especially when addressing more male audiences, that gambling by women would affect male roles, female health and family prosperity. It would break up homes, children would be underfed, and rent would be in arrears. Any evidence that betting led some women into financial difficulties was seized on with alacrity. Women's betting was argued to destroy family life. ${ }^{42}$ While this had once been a common argument, however, the extension of the suffrage brought fresh challenges to such views. The secretary of the International Women's Suffrage Alliance, for example, writing in 1924, was quick to point out that money spent by the wife on amusement and personal desires was no greater loss to the family income than money similarly spent by the husband. ${ }^{43}$ 


\section{Ways in which opposition was mounted}

Opposition to gambling took a number of forms, each with its own chronology. There were peaks and troughs in its efforts, and shifts of focus as new forms of gambling emerged. In 1922 the threat that betting duty was being considered by the government led to much more organisation and reporting of anti-gambling activity in efforts to influence the Select Committee. The new greyhound racing tracks of the late 1920s, with their regular meetings, the development of racecourse totalisators from 1929, the Irish Hospital Sweepstakes, and the 'increasing evil' of the urban Tote clubs around 1930 all generated anti-gambling activity hoping to sway the 1932/3 Royal Commission, and much of the anti-gamblers' attention was diverted away from racing towards these new betting forms. In 1934 and 1935, following the Royal Commission's report, antibetting activity was at a low ebb judging by the lack of coverage in the press, and the focus shifted to football pools betting. This was run by 'financial interests which were entirely lacking in conscience and were exploiting the community for their own ill-gotten gains', while in the industrial areas people were 'frequently' spending $5 s$ a week on football pools. ${ }^{44}$

Although the shifting arguments against betting and gaming are important in understanding the range of motivations and attitudes behind the anti-gambling campaign, the movement did far more than merely offer argument. To have any chance of influencing wider public opinion the anti-gambling groups had to engage in effective action. So what forms did anti-gambling opposition take?

There was clearly strength in numbers, and several organisations provided support. In the period at the beginning of the twentieth century the major reform pressure group had been the NAGL, a secular body, although with much Church support. ${ }^{45}$ Before the war it had offices at Westminster, Manchester and York, each publishing anti-gambling material, but it became far less influential after the First World War, and lost much of its former force. Leading figures of the pre-1914 period retired. Their efforts to counter gambling had apparently had little effect. The League had always argued that social, moral, economic and physical damage was caused by betting, and wanted not softening of the law, but further prohibition, including the banning of off-course credit betting and the publication of betting materials. For the League, betting was a national menace, and members were particularly shocked at evidence of women and children gambling. ${ }^{46}$ At a time when its membership was increasingly Churchbased, the decline of the Liberal Party and the move to secularisation in broader 
society eroded its appeal. As its membership and committee aged in the 1920s it became weaker.

The leading historian of the NAGL, David Dixon, sees it as becoming 'progressively less coherent and influential, as it slumped from crisis to crisis' ${ }^{47}$ Although it tried to create a broader base of support it was increasingly becoming an organisation of and for the churches. As a secular organisation it had previously avoided this. A first attempt was made to relaunch it by John Gulland at the beginning of the 1920s. This focused on structural changes, constitutional rationalisation, a merger of the London and provincial organisations, and new officials, though the wealthy industrialist and social researcher Seebohm Rowntree remained treasurer. The changes had little impact on membership, or financial and political support, which was eroding. In 1923 most of the NAGL were still opposed to the suggestions that prohibition should be substituted by regulation of cash bookmakers. A betting duty would not reduce betting, and would make it more difficult to deal with bookmakers, while making it appear that the State approved of betting. Although at least two of the League's members gave evidence to the Select Committee, it was otherwise largely inactive in the 1920s, with membership dropping and no money to support more active involvement. When gambling on greyhounds and on football grew too, the NAGL was not flexible enough or resourceful enough to respond.

Membership continued to fall in the early 1930s. The League was in financial difficulties and receiving an ever more sceptical reception. The executive committee was increasingly old and inactive. One key illustration of this was the failure to make any public response to the publication of the 1933 Final Report of the Royal Commission on Lotteries and Betting. The NAGL was increasingly dominated by the 'Nonconformist conscience'. Two-thirds of its vice-presidents were Church representatives by 1933, and NAGL speakers mostly spoke at Church conferences. Little material was now being produced. Attempts at another reorganisation in 1934 had little effect, although John Gulland produced policy statements on the report and related legislation, and made a public appeal for funds. Seebohm Rowntree lacked the skills to be a popular leader. ${ }^{48} \mathrm{He}$ was propping up the organisation financially and was obsessive in his opposition to gambling, but it clouded his judgement. The new committee of the NAGL was as ineffective as the old one.

As secular interest in anti-gambling declined, however, concern in the Protestant churches about gambling grew, partly as a result of the new commercial forms of gambling like greyhound racing, and because they were constantly being called upon to give a lead in responding and contributing to debates 
about betting duty and gambling. A Nonconformist of whatever class was most likely to oppose betting. Strict anti-gambling beliefs had become Protestant orthodoxy. Church figures became vociferous opponents, while the Christian Social Council also contributed to the debate. In working-class areas, missions and Nonconformist chapels were the main places were such views were propagated through meetings, leaflets and lads' clubs. The churches became the custodians of traditional morality, reflecting a Christian outlook 'no longer shared by the majority' of the population. ${ }^{49} \mathrm{New}$ cross-church organisations such as the Scottish National League against Betting and Gambling maintained an influence greater than that of the NAGL. ${ }^{50}$ Mirroring the national joint organisations were more local groups like the Anti-gambling Committee of Manchester or the Salford Council of Christian Congregations.

Wider Church support was generated as betting became a regular topic at annual convocations, assemblies and meetings of particular church groups. In the spring of 1923, for example, when the report of the Select Committee on Betting Duty was being compiled, a number of religious bodies, including the Baptist Union, the Congregational Union and the Presbyterian Church of Scotland, all passed anti-gambling resolutions, and the York Convocation also discussed it. In the summer and autumn, further resolutions came from groups like the Christian Fellowship, the Wesleyan Methodist Conference and the National Free Church Council. In a rare spirit of ecumenicalism the various religious groups also managed to work together. A Council of Action of Religious and Social Reform Organisations was set up in May 1923, and a more powerful body, the Conference of Christian Politics, Economics and Citizenship, was set up in Birmingham in April 1924, initially focusing largely on betting. ${ }^{51}$

Like some modern psychologists of gambling, such groups felt that excessive gambling was due to irrational thinking, so better education should achieve a conversion. Preaching, writing and other forms of communication would help people understand the irrationality of betting, and would change attitudes. Some hoped that the government would 'institute a publicity campaign against betting' in the interests of 'national efficiency and the general well-being of the people', or perhaps even provide 'a syllabus of instruction on the moral and economic evils of betting, exposing in particular its anti-social character' for the day schools. ${ }^{52}$

They felt that control over knowledge was power. Some wanted to cut off the public from knowledge about racing results, betting odds and tipster advertisements, and supported the introduction of legislation to do this. Betting had been 
supposedly banned in public libraries since the Library Offences Act of 1898, and public libraries in a minority of local authorities helped by cutting or blocking out racing information from newspapers, although this slowly became less common. It was, for example, discontinued in West Ham in 1928, although Wolverhampton continued through the interwar period. ${ }^{53}$ More positively, antigamblers produced articles, pamphlets and books to inform and influence opinion, although the volume of such propagandist literature was heavily outweighed by the books of guidance for bookmakers or punters. Before the Great War the NAGL had played a leading role with an annual Bulletin and leaflets from its branches helping to put forward anti-gambling arguments. After the war the NAGL's attempts keep its Bulletin going were unsuccessful. It abandoned it by late 1921, although it continued to publish annual reports addressing particular gambling issues. ${ }^{54}$ Thereafter it was left to individuals to publicise the cause. Benson Perkins, drawing greatly on his experience in a working-class area of Sheffield, was a leading social reformer who played a major role in anti-gambling activities between the war, gave evidence to the two government enquiries, and was on the committees of the various inter-denominational anti-gambling organisations. He wrote many books and articles, arguing that all commercialised bookmaking should be banned. ${ }^{55}$ John Gulland was another major figure, active in the NAGL from the beginning of the twentieth century, and later a highly efficient and hard-working secretary and organiser. He produced a whole range of anti-gambling leaflets, pamphlets and books on behalf of the NAGL and gave evidence to both enquiries. ${ }^{56}$ Canon Green was a leading national critic of gambling from the late Edwardian years to the 1930s. He addressed public meetings and wrote booklets, tracts, books and articles in the Manchester Guardian, the leading anti-gambling daily paper of the time. ${ }^{57}$

Preaching in churches and chapels was another way of promoting the cause and sermons against all forms of gambling seem to have been a commonplace in interwar churches. Mass Observation noted that gambling and drink were by far the two commonest 'social evils' attacked in the five hundred sermons it observed in Bolton. ${ }^{58}$ This may well have been effective in shaping the attitudes of at least some church congregations, but as Rev. Gillie admitted in evidence to the 1923 Select Committee, there was no attempt to go outside the Church to persuade. ${ }^{59}$ Effort was probably wasted in constant preaching to the possibly already converted. As another anti-gambler pointed out, 'you may preach all the sermons you like, the bookmakers are not there to hear them'. ${ }^{60}$

Yet few noted that many Christians and other religious believers were involved in racing and betting. In racing towns the Church of England always 
had large numbers of racing followers in its congregations. In London there were numbers of Jewish bookmakers, and in the North of England many Catholic bookmakers. In these areas where congregations were more supportive of racing and betting, there was much less anti-gambling preaching, and what little there was, was carefully focused. A Liverpool pulpit critic of Aintree, for example, attacked only the use of 'National mascots' to bring betting luck. ${ }^{61}$ Here, as elsewhere, local religious leaders kept themselves attuned to pro-racing local opinion. In more strongly anti-gambling churches, punters kept quiet.

Anti-gamblers rarely attempted the challenging task of preaching to the massed unconverted. Canon Green was exceptional in taking on the difficult, arduous and time-consuming work of anti-gambling preaching to workshops, mills and factories during the dinner hour. Through the years he lived in central Salford, Green claimed to have delivered 'scores, I might almost say hundreds of addresses in workshops and factories, in halls and in churches on gambling' ${ }^{62}$ The earlier practice of giving out tracts at the racecourse still occasionally occurred, although often subject to jeers, insults and abuse, and evangelical religious groups sometimes demonstrated inside or outside racecourses. Their placards concentrated on the punishment the racegoer would experience in the afterlife. One photograph of the road leading up to the Epsom grandstand in 1922, for example, shows a group holding large posters telling racegoers 'After Death the Judgement', 'Prepare to Meet thy Doom' or 'The Wages of Sin is Death', a phrase sometimes also projected through a megaphone just after the 'off' for maximum impact. ${ }^{63}$

If the anti-gamblers really wanted to change attitudes, then changing government policy was likely to have more fruitful results, and so the anti-gambling groups were strongly represented both on the membership of and amongst those giving evidence to the 1923 Select Committee of the House of Commons on Betting Duty, although here they now faced a somewhat more hostile reception than in previous years. Such publicly-reported political contexts were a rare and therefore important opportunity to influence public and political opinion. The texts of the exchanges demonstrate, for example, how carefully-weighted leading questions by Committee members were used in the hope of getting witnesses to agree to some extent with their cause. They show, too, the extent to which the thinking of the anti-gamblers reflected their culture, identity and social-class experience. Some of the difficulties the police faced in attempting to give their views in evidence to the Committee are also made clear. 
During the hearings there was a short exchange between one of the antibetting Welsh MPs on the Committee, Dai Grenfell, and Superintendent Evans of Glamorganshire, after Evans had presented evidence of betting in South Wales. It neatly encapsulates reference to two of the themes of this chapter: the arguments used by anti-gamblers, and the ways their opposition was mounted.

Grenfell was a former miners' agent who was elected MP for Gower in 1922 and was a staunch Nonconformist, part of a culture rooted in respectability, temperance and anti-betting. This culture was increasingly out of step with the values of South Wales mining communities, and Grenfell may well have been sensitive and defensive about that. ${ }^{64} \mathrm{He}$ began by trying to get Evans to agree that the 'whole of the public expression of opinion' in South Wales was anti-gambling, referring him to the resolutions and joint expressions from anti-gambling groups. Evans however was equivocal, saying that there 'certainly is a great opposition to betting but there is a great number otherwise'. Grenfell also suggested to him that 'useful citizens', those who have an 'interest in public life' and 'public morality', did not 'resort to gambling'. Evans suggested that 'people will bet because it is an attribute of the Britisher to bet'. This complacent myth, if held more widely, would have promoted disbelief in the effectiveness of anti-gambling legislation. Grenfell, his Welsh pride perhaps stung, seemed not to believe that 'there was a marked tendency among the Welsh people' to gamble, and asked whether it could really be a thing 'essentially Welsh', making Welshness synonymous with Britishness. This was not unusual in the rhetoric of the period. Evans avoided the question, responding that they would call it not gambling but 'a little sport'.

Grenfell's next remark, asking whether 'I do not know my own country', could be variously interpreted as new humility, scandalised dismay or sarcasm. Evans, who again avoided a direct answer, told him that 'down in Swansea where you are ... they gamble very freely'. Grenfell then challenged the notion that it was British to bet, arguing from a position of supposed racial superiority, asking if it was 'not generally well known that it is the inferior races of the world who gamble and not the superior races', placing those who bet as occupying a lower position on the evolutionary ladder. Grenfell also appealed to his own expertise, experience and political position, saying 'I represent the men and have lived with them all my life', only to be told by Evans, 'Well, they do not tell you all, you see'. ${ }^{65}$ In Wales secular activities and attitudes were eroding the hold of the chapels, and the dangers of losing touch with the community from which he came must have been an issue here. 


\section{Limited anti-gambling success}

Even in 1939 there were still strong social and economic objections to betting, but they were in process of decreasing. Betting was now simply a small part of the wider problem of the 'right' use of leisure, and of the slowly changing patterns of class relationships. What Dixon has described as the earlier 'authoritarian paternalism whose tool was prohibitory legislation' was in process of being undermined by a more democratic social philosophy. ${ }^{66}$

As a result the anti-gambling movement lacked any real unity. It was generally agreed that some restrictions needed to be placed upon organised facilities for betting and gambling, and that restrictions should certainly be imposed to help maintain public order. But thereafter there were divergent views about what should and could be done. At one end of the spectrum were more radical anti-gambling opponents who felt that not just street betting but all forms of bookmaking should be made illegal, and wanted to go further along the prohibition path to abolish credit and racecourse bookmaking. John Gulland, for example, really wanted to 'prohibit the betting trade but not private betting', yet recognised the difficulties. ${ }^{67}$ Green thought all betting was wrong. The most extreme body of all, the Scottish National League against Betting and Gambling, saw betting as a 'social and moral calamity to the state' which should not be recognised in any of its forms. ${ }^{68}$ The elimination of inducements to bet by the reduction of existing betting facilities was often proposed, though with no support from governments. Much anti-gambling evidence to the Royal Commission of 1932 urged that any amendment of the law should be in the direction of banning use of the telephone, telegraph or the post for betting purposes, along with publication of betting odds and news, or advertising of bookmaker and tipster services. They were also keen to restrict the Tote betting on racecourses to cash bets, and not allow its various credit manifestations. ${ }^{69}$

Moderates believed that the 1906 Act was enough, but needed better enforcement and more willingness from magistrates to imprison regular bookmaker offenders. Rev. Gillie, for example, pragmatically felt that it would not be possible to prohibit betting altogether, admitting that 'in legislation you have to consider what you can achieve' ${ }^{70}$ The Rev. Hon. E. Lyttleton, a former chairman of the NAGL, also recognised that to make betting absolutely illegal was impractical. So did the dean of Durham, who felt betting was not immoral in itself: it was a question of degree. Those who took the fundamentalist view that all betting was wrong actually estranged 'the great body of moderate Christian opinion', and ended up as enemies of reform. ${ }^{71}$ Moderates took the 
view that legislation banning betting would not help, and that betting was excusable if carried on in moderation. It was only a source of national demoralisation if carried to excess. That was not to say that they would not ban betting if they thought it was a practical option, and they would support anything that would reduce its level.

The NAGL was therefore disunited. Some radicals wanted more stringent action, further regulation and prohibitions. Others were prepared to accept regulation if it would tackle gambling, and some would accept betting duty as a form of regulation. A minority had come to accept that the earlier Street Betting Act prohibiting cash betting was simply not effective. The failure of liquor prohibition in the USA increased their interest in more practical and effective alternatives.

The British Civil Service was pragmatic about betting, but different departments of state had different views. Departments like the Post Office or the Exchequer were less concerned with ethics than with revenue-raising. The antigamblers had most success with the Home Office, which had to ensure the practical working of government anti-gambling legislation and so over time increasingly shared in the opposition to gambling and bookmakers, adopting a moralistic, authoritarian and paternalistic approach. Its senior officials continued this conservative approach through the interwar years, and took an uncompromising stand against any legislative changes, which they felt would be ill-informed and unworkable.

In part this was due to the way the social evils its data provided seemed to confirm that a majority of the country would oppose change. The powerful permanent under-secretary at the Home Office, Sir John Anderson, was a strong defender of gambling laws. In his evidence to the Select Committee in 1923 the legal assistant under-secretary, Blackwell, felt that changes would be bitterly opposed, not only by the Nonconformist conscience on grounds of principle, but by 'a very large section of the population'. ${ }^{72}$ The department believed that legalisation would mean more betting and increase its socially harmful effects. It strongly supported the status quo of apparent containment. Blackwell feared that otherwise the 'considerable proportion of the weekly employment dole' devoted to betting would increase still further. He felt that there was overwhelming evidence to support the view that crimes like embezzlement and larceny, and bankruptcies of firms, were mainly due to 'excessive betting. ${ }^{73}$ But when pressed by the 1923 Commission he was unable to provide firm statistical support for his views, and fell back on departmental 'common sense'.

In Parliament the Conservative Party, with a few exceptions, had a relatively positive attitude to betting. Up to 1914 the Parliamentary Liberal Party had 
been more opposed, and after 1918 many Labour MPs took a similar view, despite their constituents' more positive attitude. There was a widely held New Liberal and Fabian Society view, shared by some Labour and Liberal MPs, that while it would be impossible to stop betting totally, all professional bookmaking activity, of whatever sort, should be banned. The Labour shadow chancellor in 1923 saw gambling as 'the second greatest curse of the country'. ${ }^{74}$ Although the impact of Labour opposition on the 1923 findings was fairly limited, Isaac Foot, a member of both the 1923 Select Committee and the NAGL, but inexpert in his knowledge, prepared an alternative minority draft report. Much of the work on this was actually done by Benson Perkins, who briefed him before each hearing, and worked hard to ensure that the Committee would not recommend that betting duty was desirable. The Labour MP the Rev. James Barr opposed the Tote's introduction as another part of the 'public iniquity' of betting, and wanted to do away with all forms of betting. ${ }^{75}$ Even in 1929 Prime Minister Ramsay McDonald was quoted as seeing betting as 'leading to the demoralisation of our people', while Snowden, the chancellor, who held very strict Puritan views, regarded betting as 'the ruination of innumerable promising careers', and had the reputation within racing as always taking up 'an antagonistic attitude' to turf speculation. ${ }^{76}$ Yet the Labour Party as a whole showed little willingness to politicise the issue. Working-class betting long preceded its formation, and though Labour origins were rooted in respectability, rational recreation and Nonconformism it also had a libertarian socialist tradition, while some activists actively enjoyed betting. Unwilling to lose electoral support, ${ }^{77}$ it took little part in either sponsoring or encouraging any form of sporting activity, least of all racing, with its traditional, elitist, upper-class governing bodies, or in supporting class-based betting legislation.

Recent revisionist views arguing that the process of secularisation only really began in the 1960s get little support from this work. ${ }^{78}$ Even by 1923 the evidence seems to suggest that anti-betting arguments were in decline. The comments and draft report of the 1923 Select Committee met the argument that betting was immoral by moving to a secularist approach, one where morality was constructed by the individual and society. They argued that the millions who bet, and many others, regarded betting in no sense as either moral or sinful. They dismissed the argument that if the state recognised and controlled betting this would lower moral standards by citing those other countries which had done so, suggesting that there was no evidence that moral standards there were lower than in Britain. The churches and education had exercised any supposed moral force unavailingly over the previous twenty-five years. The arguments 
that betting caused poverty were seen as grossly exaggerated. In response to the claim that betting was the prime cause of dishonesty, the Committee cited the Home Office Returns of larceny, embezzlement and other frauds from 1906 to 1920 , pointing out that there had been a decline in links with crime over the period. The argument that betting was unproductive, and should be banned on economic grounds because it provided no goods in exchange for the punter's money, also failed to appeal. The Committee pointed out that people paid for concerts, the theatre and other leisure activities that provided no goods. Betting was part of leisure, and the person betting got pleasure and excitement in exchange. As a luxury it was therefore fit for taxation.

But to an extent the 1923 Committee still accepted some of the anti-gamblers' arguments, and reflected the concerns of previous decades. It felt that there were evils associated with betting, that excess betting was a great social ill, leading to demoralisation and suffering, and wanted to see the extinction of the street bookmaker, whom it saw as contributing to the growth in betting. The Select Committee accepted that breaking of the law by millions had a demoralising effect on character and weakened respect for law. As part of the male establishment it was especially shocked by the canvassing of women, particularly in the absence of their husbands', a clear indication of the Committee's assumptions about the male/female roles of the 1920s. The high level of street betting in the industrial regions was 'morally undesirable', especially since clandestine. Although the report was never finally completed due to the election, the subsequent return to power of the Conservatives saw the introduction of betting duty by the chancellor, Winston Churchill, in 1926, and the Racecourse Betting Act which introduced the Totalisator in 1928, although the puritan, anti-gambling home secretary W. Joynson Hicks ensured that the criminal laws against betting would not be changed.

By the time of the 1932/3 Royal Commission the concerns about betting on horseracing had been overtaken by the complex betting issues surrounding the Tote, pools, dog racing and sweepstakes, although the traditional arguments were still being reiterated and concerns to do nothing to increase gambling still dominated. The policy was now to prohibit or restrict only such facilities as had serious social consequences, and it was increasingly clear that there was a widening gap between the ideals of anti-gamblers and those in wider secular society. An exchange between the secretary of the Scottish National League against Betting and Gambling, F. Watson, and one of the commissioners, W. L. Hitchen, illustrated this well. Hitchen had suggested that betting laws had enjoyed public support. Watson dismissed this, explaining that 'The point is 
that we do not take our ethic from the man in the street', only to be told impatiently that 'The man in the street does not take his ethics from you' ${ }^{79}$

The Commission also accepted the argument that attacks on ready-money but not credit betting were simply 'class legislation'. ${ }^{80}$ They recognised that police action was largely ineffective. The major debate was whether cash betting offices should be allowed. But while the police and bookmakers both supported this, the opposing evidence of the churches, representatives of social organisations, the Association of Municipal Boroughs and the Convention of Royal Boroughs led the Commission to decide against it on the ground that it would encourage more betting. It went some way towards this by recommending that cash betting by post should be made legal and they were prepared to allow betting offices open both for credit betting and ready-money betting by letter or deposits left in collecting slots. This was a majority proposal, and had a number of practical weaknesses, while the Commission still failed to exhibit sufficient social understanding of betting contexts. As a result its proposals were rejected by the government. The possibility that any legislation would be divisive, and would stir up anti-gamblers, bookmakers, the press, the Church and the betting electorate, was too great.

In that sense, as a potential powder keg of dissension, the anti-gambling opposition should not be under-estimated. They were still the custodians of traditional morality, and were able to exert a powerful influence, not for change, but for inertia, for the maintenance of the status quo. Christianity continued to influence many aspects of civic society and social behaviour, and Christian attitudes to betting thus helped to shape the character of Britain between the wars. ${ }^{81}$

This Christian outlook was no longer shared by the majority of the population. Britain was an increasingly secular society. In relation to leisure its character was changing. So despite their continued political and cultural influence, in terms of public perceptions the anti-gamblers were increasingly portrayed as out of touch, single-issue fanatics. They were becoming subject to ridicule. British cultural forms almost all reflected a pro-gambling approach. A 1928 David Low cartoon shows a deputation approaching Winston Churchill. In the background a large, lively and excited crowd are queuing for a dog-racing stadium. A newspaper boy is selling the Daily Gamblerwith its racing selections. A series of wall posters advertise 'Toy Gamble', 'Monte Carlo Cigarettes - Free Roulettes' and other gambling services. The deputation of 'Right-Thinking Persons' addresses Churchill, asking him politely, 'Sir, is not this appalling increase of the gambling spirit among us threatening the fabric of our social 
system and sapping that thrift which is the foundation of our national greatness?' Churchill replies in vox pop mode, 'I'll bet yer it isn't'. ${ }^{82}$

The anti-gamblers between the wars built on earlier traditions, when they had enjoyed a measure of success in promoting betting legislation. But they failed to respond sufficiently strongly to the economic, social and political changes of the 1920 s and 1930s. The anti-gamblers represented an old form of cultural dissent, often derived from their Christian faith and a view of work and rational recreation rooted in the Protestant ethic. They made little attempt to adapt or update the programme in the light of the changing secularisation of society, the increased 'social problem' of leisure, or the changing forms of commercial culture and the betting market. A cultural dynamic in which puritanism was increasingly vying with alternative views was reshaping British society, and the central imperatives of anti-gambling were becoming increasingly threatened by inner contradictions. ${ }^{83}$

Those opposed to gambling failed to make use of the new forms of mass media - the cinema, the popular press or the radio - in ways which might have challenged the dominant pro-betting rhetoric. Indeed they sneered at and showed little knowledge of such media. They continued to use traditional forms of communication which were increasingly less heard or read. The detachment of many, though not all, from the realities of contemporary life meant that their reform agenda failed to galvanise the general population, and their ageing arguments were continually reiterated in the face of public apathy.

\section{Notes}

1 Mass Observation, The pub and the people [1943] (London: Cresset Library, 1987), p. 44.

2 See Mike Huggins, Flat racing and British society 1790-1914 (London: Frank Cass, 2000), pp. 204-11.

3 North-Eastern Daily Express, 18.8.1922.

4 For example, The Times, 30.3.1922; ibid., 1.6.1922.

5 Huggins, Flat racing, ch. 8, passim; David Dixon, From prohibition to regulation: bookmaking, anti-gambling and the law (Oxford: Clarendon Press, 1991), ch. 2 .

6 Richard Dyer, 'Entertainment and Utopia', in Rick Altman (ed.), Genre, the musical: a reader (London: Routledge, 1981), pp. 177-89.

7 See Edward Devereux, Gambling and the social structure (New York: Arno Press, 1980,) pp. 919-20, 937-8.

8 Peter Green, Betting and gambling (London: Student Christian Movement, 1934), p. 11.

91923 Select Committee on Betting Duty, report with minutes of evidence, Q7085 (Green). 
10 1932-3 Royal Commission on Lotteries and Betting, Appendices, Christian Social Council statement, p. 260.

11 Michael B. Walker, The psychology of gambling (Oxford: Pergamon Press, 1992), p. 132.

12 Quoted in The Times, 21.4.1923.

13 W. Temple and E. B. Perkins, Gambling and ethics (London: Pilgrim Press, n.d.).

14 Liverpool Post, 24.3.1925.

151923 Select Committee on Betting Duty, QQ5578, 5632 (Perkins); QQ6898, 6993 (Green); Q7347 (Lyttelton).

16 Cecil H. Rose, Gambling and Christian ideals (London: Epworth Press, 1930), p. 1.

17 see Huggins, Flat racing, pp. 204-28.

18 Green, Betting and gambling, pp. 69-3.

191923 Select Committee, Appendix IV, 'Can We Support the Betting Tax?', United Council of Action.

20 1932-3 Royal Commission, ch. IV, para. 186.

211923 Select Committee, Appendix IV, 'Can We Support the Betting Tax?', archbishop of York.

221923 Select Committee, Q5569 (Perkins).

231923 Select Committee Q5616 (Perkins).

24 Arthur Shadwell, Industrial efficiency: a comparative study of industrial life in England, Germany and America (London: Longmans, Green and Co., 1920), p. 509.

25 Report of District Conference of Chief Constables, District no. 1, Blackburn, 4.5.1923.

261923 Select Committee, QQ6768, 6789, 6804-5 (Green). Green, Betting and gambling, pp. 34-7.

27 Dixon, From prohibition to regulation, p. 204.

28 Rev. Dr John Clifford in speech to the Baptist Union, reported in The Times, 24.4.1923.

29 The Times, 20.4.1923.

30 1932/3 Royal Commission, report paras 215-16; Astbury statement, p. 379 para. 4; Burgess, Q2215.

31 1932/3 Royal Commission, report para. 216.

32 See Dixon, From prohibition to regulation, pp. 321-9.

33 Bulletin 6:74 (May 1919), 109, quoted by Dixon, From prohibition to regulation, pp. 298-9.

34 Headlines frequently called attention to these, although they often formed a persuasive part of a plea. See for example 'Bank Clerk's Bets. Tempted to steal money to get straight - a plea for leniency', Liverpool Echo, 13.1.1922.

351923 Select Committee, QQ6766, 6826 (Green).

36 1932/3 Royal Commission, report paras 211-13; Bigham, QQ550-2, Knight statement, p. 220 para. 17; Biron, Q3080; Burgess statement, p. 145 para. 2; Brook Statement, p. 64 para. 26.

37 See Green, Betting and gambling, p. 50.

38 Ibid., p. 54. 
39 1932/3 Royal Commission, Chamberlain statement, p. 300; Lamb statement, p. 176; Lockwood, QQ3609, 3649.

401923 Select Committee, Q7354 (Lyttleton).

411923 Select Committee Appendix IV, 'Can we Support the Betting Tax?', United Council of Action.

42 See Carl Chinn, Better betting with a decent feller: bookmaking, betting and the British working class, 1750-1990 (Hemel Hempstead: Harvester, 1991), p. 172.

43 The Times, 11.1.1924.

44 Ibid., 31.3.1938.

45 See Dixon, From prohibition to regulation, pp. 82-108, 149-85; Huggins, Flat racing, pp. 220-5.

46 Mark Clapson, A bit of a flutter: popular gambling and English society c. 1823-1961 (Manchester: Manchester University Press, 1992.

47 Dixon, From prohibition to regulation, p. 299. The following two paragraphs are largely based on his work.

48 See A. Briggs, Social thought and social action: a study of the work of Seebohm Rowntree 1871-1954(London: Longmans, 1961).

49 John Stevenson, British society 1914-1945 (Harmondsworth: Penguin, 1984), p. 370 .

50 Roger Munting, An economic and social history of gambling in Britain and the USA (Manchester: Manchester University Press, 1996), p. 35.

51 COPEC, $A$ report of the meetings of the conference on Christian politics, economics and citizenship held in Birmingham, April 5-12, 1924 (London: Longmans, Green, 1924).

52 Rev. Hugh Jenkins, reported in The Times, 13.5.1924.

53 The Times, 28.11.1928; Chinn, Better betting, pp. 220-1, A. H. Thompson, Censorship in public libraries in the twentieth century (Epping: Bowker, 1975).

54 For example NAGL, The great waste and the cure: 31st annual report (London: NAGL, 1921); NAGL, Gambling and the state: 43rd Annual report (London: NAGL, 1933). Amongst other major anti-gambling works should be included Rose, Gambling and Christian ideals, and J. Bretherton, Why gambling is wrong (Manchester: Purpose Publications, 1936).

55 E. B. Perkins, The problem of gambling (London: Epworth Press, 1919), Betting facts (London: Wesleyan Methodist Church and SCM, 1925) and Gambling and youth (London: Sunday School Union, 1933).

56 Good examples of his work are John Gulland, Gambling: the modern problem (London: NAGL, 1932) and Youth and gambling (London: British Christian Endeavour Union, 1936).

57 See Peter Green, Is gambling morally wrong? (London: Friends Book Centre, 1926) and Betting and gambling (London: Student Christian Movement, 1924).

58 Mass Observation, The pub and the people (1987), p. 162.

591923 Select Committee, QQ6086-93 (Gillie).

601923 Select Committee, Q6709 (Welldon).

61 Liverpool Echo, 24.3.1938. 
62 Green, Betting and gambling, p. 11.

63 'Coaching to Epsom', Central Press, 1922, in Michael Wynn Jones, The Derby (London: Croom Helm, 1979), p. 174. See also Jack Fairfax-Blakeborough, The analysis of the turf(London: Philip Allan, 1927), pp. 3-4.

64 See Kenneth O. Morgan, Rebirth of a nation: Wales 1880-1989 (Oxford: Oxford University Press, 1982), p. 198.

651923 Select Committee Q5432-50.

66 Dixon, prohibition to regulation, p. 354.

671923 Select Committee, Q6280 (Gulliland).

681932 Royal Commission, Watson statement, p. 164.

691932 Royal Commission, Church of Scotland statement, p. 151; Christian Social Council statement p. 261; Gulland statement, pp. 185-7.

701923 Select Committee, Q5947 (Gillie).

711923 Select Committee, QQ6452, 6586 (Welldon).

72 Home Office Memorandum, 15.2.1923, quoted in Dixon, From prohibition to regulation, p. 191.

73 Blackwell memos and letters, quoted in Dixon, From prohibition to regulation, pp. 195-6.

74 Dixon, From prohibition to regulation, p. 189.

75 Quoted in Stephen Jones, Workers at play: a social and economic history of leisure 1918-1939(London: Routledge, 1986), p. 172.

76 The Times, 22.2.1929; The Racing World and Newmarket Sportsman, 5.7.1929.

77 See Stephen Jones, 'The British Labour movement and working class leisure 1918-1939', unpub. Ph.D., University of Manchester, 1983, pp. 208-25; Chinn, Better betting, pp. 190-1.

78 Callum Brown, The decline of Christian Britain (London: Routledge, 2000).

791933 Royal Commission, minutes of evidence, p. 171, QQ2537-8.

801933 Royal Commission, report para. 279.

81 Stevenson, British society 1914-1945, p. 370.

82 David Low, 'The Sporting life', Evening Standard, 21.1.1928.

83 The more theoretical work on gambling in American society before and after the Second World War, carried out by Goffman and Devereux, certainly seems to support such a view, and there are strong similarities with British society. See D. M. Downes, B. P. Davies, M. E. David and P. Stone, Gambling, work and leisure: a study across three areas (London: Routledge and Kegan Paul, 1976), p. 28. 